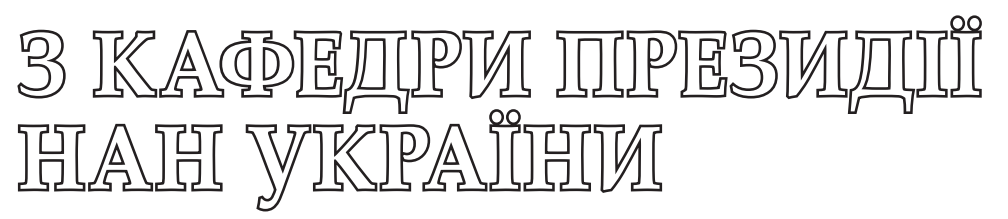

doi: https://doi.org/10.15407/visn2021.09.021

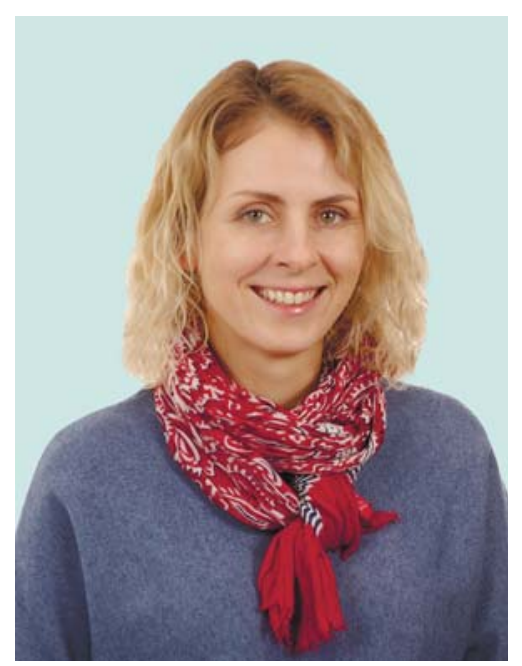

\title{
ТЕРИТОРІАЛЬНИЙ РОЗВИТОК УКРАЇНИ В КОНТЕКСТІ ВИКОНАННЯ УГОДИ ПРО АСОЦІАЦІЮ УКРАЇНИ 3 ЄС
}

\author{
За матеріалами доповіді на засіданні \\ Президії НАН України 7 липня 2021 року
}

МАРУНЯК

Євгенія Олександрівна член-кореспондент НАН України, директор Інституту географії НАН України

У доповіді акиентовано увагу на рамкових умовах реалізації політики $Є С$ y сфері територіального/просторового розвитку, потребі запровадження в Україні окремих підходів та механізмів для забезпечення сталого (збалансованого) територіального розвитку громад, регіонів та держави загалом, а також на виконанні положень Угоди про асоціацію з СС. Зазначено, що у відповідному напрямі Інститут географії НАН України тривалий час проводить дослідження, спрямовані на комплексне оцінювання територіального капіталу, впливів на навколишнє середовище, забезпечення наукового супроводу планування територій. Особливий акцент зроблено на підтримиі імплементації Директиви ЄС про оцінку впливу окремих планів і програм на навколишнє середовище та процедури стратегічної екологічної оцінки.

Підписавши у 2014 р. Угоду про асоціацію з СС, Україна офіційно задекларувала вектор інтеграції, невизначеність якого від часу здобуття незалежності об'єктивно було визнано однією 3 передумов слабкості позицій держави на глобальному рівні.

Водночас здійснений вибір зумовив потребу суттєвого перезавантаження цінностей і стандартів українського суспільства та управлінських структур, започаткування низки реформ, 3окрема реформи з децентралізації, посилення уваги до міжсекторальної взаємодії, комплексного підходу до розвитку територій.

В основі таких змін лежить, зокрема, і впровадження політики територіального/просторового розвитку країн $\mathrm{CC}$, яка грунтується на таких тематичних осях, як політика міського розвитку, згуртованості, просторового планування. Формування цієї політики відбувається з урахуванням глобальних викликів та ініціатив, спрямованих на пошук відповідей, - Порядку денного на XXI століття, Цілей сталого розвитку до 2030 року, конвенцій щодо навколишнього середовища та розвитку, прийнятих на Конференції ООН у Ріо-де-Жанейро. Крім того, слід підкреслити наявність та стимулювання взаємодії політики просторового розвитку з іншими секторальними політиками. 
Одним 3 ключових документів щодо просторового розвитку є Європейська перспектива просторового розвитку (European Spatial Development Perspective - ESDP), прийнята в СС у 1999 р. Вона проголошує три цілі європейської політики: економічна та соціальна згуртованість, збереження та управління природними ресурсами і культурною спадщиною, більш збалансована конкурентоспроможність європейської території. Надалі зміст цілей розкривається ширше: досягнення поліцентричного та збалансованого просторового розвитку з відповідною увагою до розвитку урбанізованих та сільських територій і забезпечення партнерства між ними; рівномірний доступ до інфраструктури та знань; розумний менеджмент природної та культурної спадщини, зокрема культурних ландшафтів. Для досягнення цілей сформульовано 60 параметрів, відносно рівномірно розподілених за напрямами [1].

Серед основних аспектів просторового розвитку ЄC у контексті сучасних викликів та тенденцій - міський розвиток, що включає питання появи міських мереж, зміни європейської міської системи та економічних можливостей міст, субурбанізації, зростаючої соціальної сегрегації в містах, поліпшення якості міського середовища. Крім того, розглядаються тенденції розвитку сільських територій, зміни їх ролі і функції, зміни у сільському й лісовому господарстві та відповідні наслідки для економіки і землекористування, транспортні мережі та проблеми їх інтеграції, зростаючі транспортні потоки та навантаження, диспропорції у поширенні знань та інновацій, ризики для водних ресурсів, зростаючий тиск на культурні ландшафти і спадщину.

Цей документ набув розвитку за трьома напрямами: 1) продовження співпраці країнчленів у рамках заснованої в 1970 р. Європейської конференції міністрів, відповідальних за просторове/регіональне планування, при Раді Європи (CEMAT) [2]; 2) Програма транскордонного співробітництва INTERREG; 3) Європейська мережа просторового моніторингу та політик (ESPON).
Завданням CEMAT, що об'єднує представників 47 європейських держав, є «просування територіального виміру прав людини та демократії для сталого просторового розвитку Європи». Це - «мережа для співробітництва щодо просторового планування, що функціонує як платформа для дискусій та обміну найкращими практиками у сфері політики просторового розвитку країн СС». Особливо слід відзначити відповідність мети СЕМАТ принципам сталого розвитку (iї чітко задекларовано у прийнятій резолюції, яка містить «Керівні принципи сталого просторового розвитку європейського континенту»), що означає поєднання соціальних та економічних вимог із забезпеченням повноцінного виконання екологічних та культурних функцій території. Саме в рамках цієї платформи було напрацьовано понятійний апарат, певною мірою співзвучний визначенням територіального і просторового розвитку. Останній ми розуміємо як «заплановану та обгрунтовану на основі збалансованого врахування суспільних інтересів та ємності/ стійкості природних і природно-антропогенних ландшафтів трансформацію соціальноекономічного простору».

Істотний вплив на формування і реалізацію політики просторового розвитку Європейського Союзу мав документ «Територіальний порядок денний ЄС до 2020» (Territorial Agenda of the European Union), положення якого наразі відображені в концепціях просторового розвитку на національному рівні. Його пріоритетами стали: поліцентричний і збалансований територіальний розвиток; інтегрований розвиток міст, сільських та особливих територій; територіальна інтеграція у транскордонних i транснаціональних функціональних регіонах; забезпечення глобальної конкурентоспроможності регіонів, що грунтується на сильних локальних економіках; поліпшення територіальної зв'язності для індивідів, громад, підприємств; управління та об'єднання екологічних, ландшафтних і культурних цінностей регіонів. Оновлений «Територіальний порядок денний ЄC 2030» привніс низку нових акцентів, таких як забезпечення просторової справедли-

ISSN 1027-3239. Visn. Nac. Acad. Nauk Ukr. 2021. (9) 
вості та «зв’язності» місць, як цифрової, так i фізичної, підтримка функціональних регіонів, прагнення до кліматичної нейтральності соціально-економічної діяльності, перехід до циркулярної економіки.

На національному рівні положення Європейської перспективи просторового розвитку було взято за основу при розробленні відповідних концепцій просторового розвитку. Так, цілями Концепції просторового розвитку $\mathrm{Hi}$ меччини (2006) стали: зростання та інновації; забезпечення послуг, що становлять громадський інтерес; збереження ресурсів; трансформація культурних ландшафтів. Для досягнення останньої цілі широко використовувався механізм ландшафтного планування, під яким розуміють «просторове планування навколишнього середовища, спрямоване на вивчення мультифункціональності ландшафтів» [3].

У польській Концепції просторового розвитку до 2030 р. [4] зазначено, що «документ покликаний зруйнувати існуючу дихотомію просторового планування та соціально-економічного планування на національному, регіональному ${ }^{*}$ і локальному рівнях, так само як i по відношенню до функціональних просторів. Він корелює цілі просторової та регіональної політики, поєднує стратегічне планування 3 програмними заходами програм розвитку та операційних програм, що фінансуються СC, визначає дії, які мають бути зроблені державою в законодавчому та інституційному полі 3 огляду на посилення ефективності системи просторового планування та діяльності щодо місцевого розвитку». Так само і в Чехії [5], де просторова політика - «серед інструментів досягнення гармонії між інвестиційними проєктами та можливостями території, як зазначено, наприклад, у Національному плані розвитку та Стратегії регіонального розвитку».

Зазначені підходи та положення втілюються і на місцевому рівні, при плануванні розвитку європейських громад.

Загалом особливостями планувальних підходів європейських країн на сьогодні є акцен-

\footnotetext{
* В оригіналі - воєводства.
}

ти щодо застосування так званого локалізаційного підходу (place-based approach), інтеграції секторальних політик, планування «функціональних територій» та залучення громадян у процеси планування. Так, аналіз, проведений у рамках проєкту COMPASS (програма ESPON) щодо управління територіями та просторового планування 32 європейських країн протягом 2000-2016 рр., свідчить про особливо виражену інтегрованість політики просторового планування з політиками у сфері транспорту та збереження навколишнього середовища (найменш інтегрованими залишалися торгівля, охорона здоров'я та освіта). При цьому на національному рівні пріоритетність інтегрованості розподілялася в такій послідовності: транспорт, навколишнє середовище, культурна спадщина й туризм, енергетична політика; на місцевому рівні - культурна спадщина i туризм, житлово-комунальне господарство, управління відходами та водними ресурсами, транспорт та навколишнє середовище.

Формування відповідного інституційного середовища в Україні у цей самий період відбувалося досить повільно. У 2001 р. було затверджено Генеральну схему планування території України, яка за своїм змістом певною мірою корелювала з настановами ESDP і встановлювала планувальні обмеження та надавала рекомендації для розроблення документів територіального планування нижчих рівнів. Водночас ці рекомендації не було враховано при розробленні Державних стратегій регіонального розвитку (до 2015 року і до 2020 року), інших стратегій (наприклад, Стратегії державної екологічної політики) тощо. Ці прогалини можуть бути заповнені при реалізації Державної стратегії регіонального розвитку на 2021-2027 роки, перевагами якої є акцентування на взаємозв’язках 3 документами просторового планування; комплексний підхід; цільові напрями та диверсифікація заходів. Крім того, це перша стратегія, в якій приділено увагу розвитку функціональних територій (гірських, приморських, прикордонних, периферійних, агломерацій тощо). Рекомендації щодо виділення та підтримки таких функціональних територій неодноразово нада- 


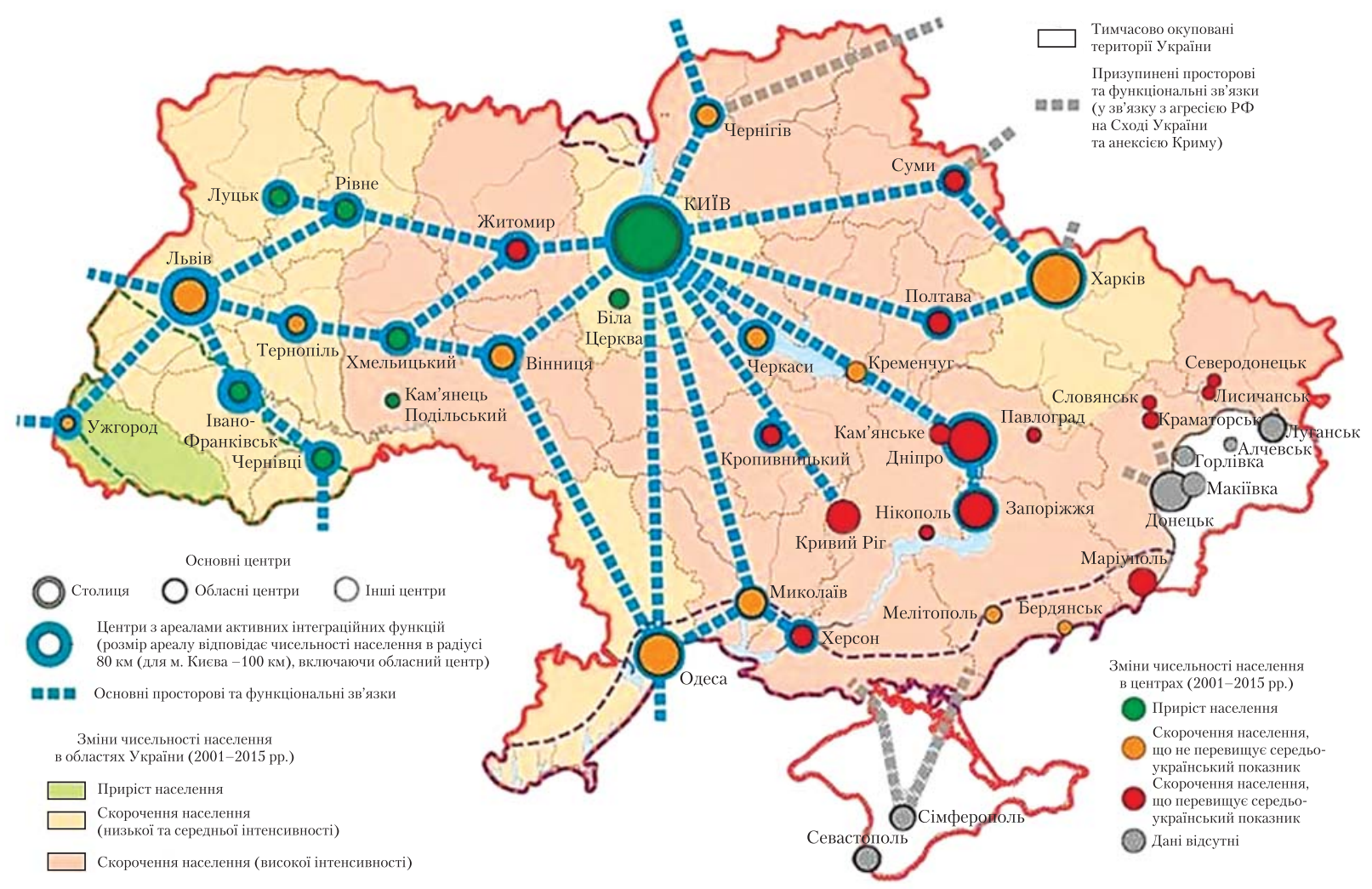

Puc. 1. Просторова інтеграція України

вали органам державної влади Інститут географіï НАН України та інші географічні осередки. Як один з прикладів можна навести запропоновану концепцію просторої інтеграції України (візуалізовано на рис. 1).

Отже, поряд з іншими чинниками повільне формування інституційного середовища для забезпечення просторового розвитку на засадах збалансованості 3 урахуванням європейських підходів призвело до укорінення в державі таких проблем, як міжрегіональні диспропорції соціально-економічного розвитку, незбалансованість просторового каркасу (неконтрольована концентрація населення в межах Києва та його приміської зони на тлі деградації сільської місцевості багатьох регіонів) [6], низький ступінь зв'язності території (низька доступність навіть великих регіональних центрів), деградація навколишнього середовища в більшості регіонів України. Розрахований за авторською методикою [7] індекс просторо- вого розвитку модельних регіонів України також засвідчив суттєві дисбаланси.

Тому в плані успішного виконання Угоди про асоціацію з СС для України була і залишається актуальною проблема наукового супроводу імплементації окремих директив, а також формування рамкових умов іiі виконання, до яких слід віднести і питання забезпечення сталого просторового розвитку.

Звертаючись до конкретних директив, насамперед слід зупинитися на Директиві № 2001/42/ЄС, яка стосується оцінки впливу окремих планів і програм на навколишне середовище і впровадження якої в Україні, незважаючи на прийнятий Закон України «Про стратегічну екологічну оцінку» (№ 2354-VIII), потребує суттєвого вдосконалення та систематизації сучасних підходів до оцінювання стану та властивостей компонентів навколишнього середовища i, безумовно, вирішення проблеми якості та доступності геопросторових даних.

ISSN 1027-3239. Visn. Nac. Acad. Nauk Ukr. 2021. (9) 


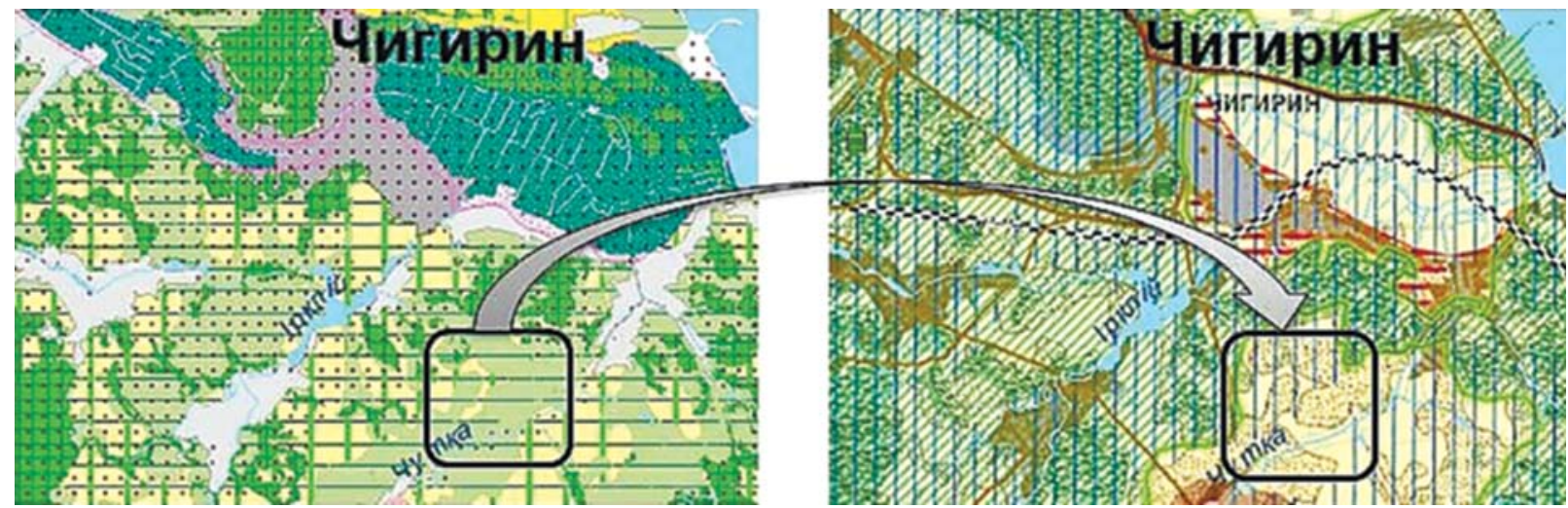

Puc. 2. Урахування в проєктному плані рекомендацій ландшафтної програми Черкаської області: $a$ - ландшафтна програма (заліснення або створення лук на місці ландшафтів, деградованих через змив грунтів); $\sigma$ - проєктний план (режим перспективного використання - запобігання деградації грунтів) [8, с. 70]

У цьому контексті особливого значення набувають виконані в Інституті географії НАН України міжнародні проєкти у сфері екологізації територіального/просторового планування. Дослідження, розпочаті у 2010 р. в рамках Програми консультативної допомоги з охорони навколишнього природного середовища у країнах Центральної та Східної Свропи, Кавказу та Центральної Азії, дали змогу врахувати європейські та національні методичні підходи у сфері оцінювання територій, запропонувати адаптовану методику ландшафтного (екологічно орієнтованого) планування, здійснити iï апробацію на рівні області, району, сільської ради, а згодом - територіальної громади. Крім того, було розроблено механізм інтеграції екологічних рекомендацій та обмежень у нормативні документи щодо територіального планування.

Встановлено, що ландшафтне планування дає підгрунтя для виконання в подальшому таких завдань схеми планування території:

- обгрунтування майбутніх потреб і визначення пріоритетних напрямів використання територій, у тому числі для містобудівних цілей, на основі принципів сталого розвитку;

• визначення територій, що мають особливу екологічну, рекреаційно-оздоровчу, наукову, естетичну, історико-культурну цінність, встановлення передбачених законодавством обмежень на їх планування, забудову та інші види використання;
- розроблення містобудівних заходів з охорони навколишнього середовища та раціонального використання природних ресурсів; охорони і збереження нерухомих пам'яток археології; захисту території і населення від небезпечних природних і техногенних процесів.

Приклад урахування рекомендацій ландшафтної програми на рівні області наведено на рис. 2.

Зважаючи на те, що ландшафтний план передбачає формування досить великої бази вихідних даних про природні умови території та оцінку стану компонентів довкілля, їх чутливості, ризиків деградації в результаті господарської діяльності, ці проєкти сприяли впровадженню в Україні сучасних європейських підходів до здійснення стратегічної екологічної оцінки (CEO).

Крім того, використання ландшафтного планування має опосередкований вплив на впровадження Директиви № 2008/50/СС «Про якість атмосферного повітря і чисте повітря для Свропи», Директиви № 2000/60/СС «Про встановлення меж діяльності Співтовариства у сфері водної політики» (зі змінами і доповненнями), Директиви № 2007/60 СС «Про оцінку та управління ризиками затоплення», Директиви № 91/676/СС «Про захист вод від забруднення, спричиненого нітратами з сільськогосподарських джерел» (зі змінами і доповненнями, внесеними Регламентом ( $\mathrm{CC}$ ) № 1882/2003) тощо. 
У рамках здійснення стратегічної екологічної оцінки підходи ландшафтного планування нині застосовуються при виборі та обгрунтуванні низки просторових показників для оцінки компонентів навколишнього середовища та часткової автоматизації таких оцінок; безпосередньому розробленні звітів про СЕО для модельних громад та різних видів документів державного планування; підготовці методичних рекомендацій для забезпечення прозорої та об'єктивної процедури СЕО при плануванні розвитку громад. Так, на прикладі схеми планування території Степанецької територіальної громади Черкаської області у звіті про СЕО за бальною шкалою було оцінено та візуалізовано їі можливий вплив за такими аспектами:

- стан здоров’я населення: очікувана тривалість життя; захворюваність; шумове забруднення;

- клімат і атмосферне повітря: викиди парникових газів; хімічне забруднення;

- земельні ресурси: забудова; утворення відходів;

- грунти: хімічне забруднення; водоутримувальна функція;

- поверхневі і підземні водні ресурси: водомісткість; хімічне забруднення;

- види і біотопи (відповідає компоненту «Біологічне різноманіття» Директиви СС щодо CEO): виснаження ареалів видів, занесених до Червоної книги; забруднення і виснаження лісових площ;

- історико-культурні ландшафти та рекреаційно-туристичні ресурси: виснаження і забруднення.

Одним із нових підходів, застосованих для територіальної громади, стала підготовка паспортів впливу кількох значущих об'єктів плану за раніше поданими консультантами прикладами німецьких громад.

Як приклад успішного впровадження наших розробок можна навести участь фахівців Інституту географії у підготовці звіту про СЕО Програми транскордонного співробітництва між Україною, Польщею та Білоруссю INTERREG NEXT.
Після ухвалення Закону України від 17.06.2020 № 711-IX «Про внесення змін до деяких законодавчих актів України щодо планування використання земель», у якому визначено поняття комплексного плану просторового розвитку, концепції інтегрованого розвитку, приділено увагу ландшафтному плануванню, більш детальні методичні напрацювання Інституту географії знайшли відображення при підготовці проєктів постанов Кабінету Міністрів України «Про затвердження Порядку розроблення, оновлення, внесення змін та затвердження містобудівної документації на місцевому рівні» та «Про визначення формату електронних документів комплексного плану просторового розвитку території територіальної громади, генерального плану населеного пункту, детального плану території».

Також важливими в контексті євроінтеграції стали дослідження Інституту, спрямовані на забезпечення збалансованого міського розвитку та управління культурною і природною спадщиною. В площині міського розвитку йдеться про визначення функцій сучасних міст в умовах глобалізації, аналіз процесів метрополізації в Україні, рекомендації щодо інтеграції принципів збалансованого природокористування у процес планування розвитку приміської зони, розроблення індикаторів та маркерів збалансованості розвитку міського простору. Щодо культурної та природної спадщини, збереження якої є однією з ключових тем Територіального порядку денного $\mathrm{CC}$, досягненням останніх років стала підготовка атласу «Населення України та його природна і культурна спадщина», що став предметом зацікавленості не лише науковців, а й управлінських структур [9].

Крім того, Інститут продовжує дослідження в рамках цільової комплексної міждисциплінарної програми наукових досліджень НАН України з проблем сталого розвитку та раціонального природокористування в умовах глобальних змін навколишнього середовища, зокрема щодо забезпечення інтеграції цілей та індикаторів сталого розвитку до 2030 року на регіональному та місцевому рівні. На

ISSN 1027-3239. Visn. Nac. Acad. Nauk Ukr. 2021. (9) 
сьогодні в більшості регіональних стратегій є прогалини, пов'язані з репрезентацією екологічної складової, окремих цілей сталого розвитку, зокрема щодо адаптації до зміни клімату, управління водними ресурсами, збалансованого планування та розвитку населених пунктів.

3 огляду на те, що зараз триває реформування містобудівної діяльності, в Інституті й надалі здійснюватиметься науковий супровід вдосконалення планувального процесу на різних рівнях та посилення методичного забезпечення виконання СЕО.

Серед інших робіт Інституту, важливих у контексті виконання УГоди про асоціацію 3 ЄC та інших міжнародних зобов'язань України, можна назвати дослідження, спрямовані на розширення мережі природоохоронних те- риторій, забезпечення сталого розвитку сільських територій та міських поселень.

На завершення слід зазначити, що для успішного вирішення поставлених завдань необхідно приділяти більше уваги налагодженню тісної співпраці з профільними міністерствами та відомствами, розширенню контактів з територіальними громадами та їх асоціаціями, проведенню комплексної оцінки територіального капіталу, оцінки впливів на навколишнє середовище для забезпечення сталого (збалансованого) розвитку територіальних громад, регіонів та держави в цілому. Значний інтегрувальний потенціал для цього має методологія географічної науки, яка в багатьох європейських країнах є основою для розроблення політики просторового розвитку.

\section{REFERENCES}

\section{[СПИСОК ЛІТЕРАТУРИ]}

1. European Spatial Development Perspective. Towards Balanced and Sustainable Development of the Territory of the European Union. http://ec.europa.eu/regional_policy/sources/docoffic/official/reports/pdf/sum_en.pdf

2. Council of Europe Conference of Ministers Responsible for Spatial/Regional Planning. http://www.coe.int/t/dgap/ localdemocracy/cemat/default_en.asp

3. European Landscape Convention. https://rm.coe.int/CoERMPublicCommonSearchServices/DisplayDCTMConte nt?documentId $=09000016802 \mathrm{f} 3 \mathrm{fc} 0$

4. National Spatial Development Concept 2030 Poland. Ministry of Regional Development. Warsaw, 2012. http://www. esponontheroad.eu/dane/web_espon_library_files/682/national_spatial_development_concept_2030_summary. pdf

5. Spatial development policy of the Czech Republic. Ministry for Regional Development of the Czech Republic. http:// www.mmr.cz/getmedia/d4c83328-afac-41ca-a6a3-78b6082ab805/2008_XII_17-PUR_2006_ENG.pdf?ext=.pdf

6. Maruniak Eu.O. Spatial development of Ukraine in global vision. Visn. Nac. Akad. Nauk Ukr. 2020. (4): 73-83. DOI: https://doi.org/10.15407/visn2020.04.073

[Маруняк Є.О. Просторовий розвиток України в глобальній візії. Вісник НАН України. 2020. № 4. С. 73-83. http://www.visnyk-nanu.org.ua/sites/default/files/files/Visn.2020/4/Visn_4-2020\%2BMaruniak.pdf ]

7. Maruniak Eu.O. Geospatial research and planning practice: Ukraine against the background of global trends (Heoprostorovi doslidzhennia i praktyka planuvannia: Ukraina na tli svitovykh trendiv). Kyiv: Feniks, 2018. (in Ukrainian). https://igu.org.ua/sites/default/files/pdf-text/geoprostir.pdf

[Маруняк Є.О. Геопросторові дослідження і практика планування: Україна на тлі світових трендів. Київ: Фенікс, 2018.]

8. Rudenko L.G. (ed.) Methods of integration of the ecological component of development into the spatial planning of Ukraine (regional level) (Metodyka intehratsii ekolohichnoi skladovoi rozvytku u prostorove planuvannia Ukrainy (rehionalnyi riven)). Kyiv, 2016. (in Ukrainian). https://igu.org.ua/sites/default/files/pdf-text/methodics-plan.pdf [Руденко Л.Г., Маруняк С.О., Палеха Ю.М. Методика інтегращії екологічної складової розвитку у просторове планування Украӥни (регіональний рівень). Київ, 2016.]

9. Rudenko L.H. Atlas "Population of Ukraine and its Natural and Cultural Heritage". Visn. Nac. Akad. Nauk Ukr. 2021. (3): 29-34. DOI: https://doi.org/10.15407/visn2021.03.029

[Руденко Л.Г. Атлас «Населення України та його природна і культурна спадщина». Вісник НАН Украйни. 2021. № 3. C. 29-34. http://visnyk-nanu.org.ua/ojs/index.php/v/article/view/6/6 ] 


\section{Eugenia O. Maruniak}

ORCID: https://orcid.org/0000-0002-6743-6883

Institute of Geography of the National Academy of Sciences of Ukraine, Kyiv, Ukraine

\section{TERRITORIAL DEVELOPMENT OF UKRAINE WITHIN THE CONTEXT OF IMPLEMENTATION OF THE ASSOCIATION AGREEMENT BETWEEN THE EUROPEAN UNION AND UKRAINE}

According to the materials of report at the meeting of the Presidium of NAS of Ukraine, July 7, 2021

The report focuses on the framework conditions for the implementation of EU policy in the field of territorial/spatial development, the need to implement in Ukraine certain approaches and mechanisms to ensure sustainable (balanced) territorial development of communities, regions and the state as a whole, as well as the implementation of the Association Agreement. It is noted that the Institute of Geography of the NAS of Ukraine for a long time has been conducting relevant research aimed at comprehensive assessment of territorial capital, environmental impacts, provision of scientific support for spatial planning. The importance and ways of implementation of the Directive 2001/42/EC on the assessment of the effects of certain plans and programmes on the environment and the procedure of Strategic Environmental Assessment is particularly emphasized.

Keywords: spatial development, territorial management, territorial planning, European Union-Ukraine Association Agreement. 